\title{
Corporate Performance Of Privatized Firms In Vietnam
}

Thi Quy Vo, Asian Institute of Technology, Thailand and University of Economics of HCM City, Vietnam

Fredric William Swierczek, Thammasat University, Thailand

Duc Khuong Nguyen, IPAG Business School, France

\begin{abstract}
We investigate the impacts of state shareholding, corporate culture and employee commitment on corporate performance of privatized firms in the Vietnamese context. Using data collected from a structured questionnaire as well as companies' annual reports, we show that only organizational integration significantly affects the performance of privatized firms. Furthermore, employee and customer satisfactions are among the most important drivers of corporate performance. Finally, there is evidence to suggest that privatized firms with less state ownership perform better than those with more state ownership.
\end{abstract}

Keywords: Corporate Performance; Vietnam; Employee Commitment; Corporate Culture

\section{INTRODUCTION}

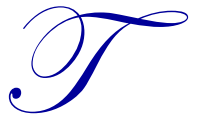

he transition from the centralized-planning economy to the market-based economy in Vietnam began with the Sixth Communist Party Congress (1986) and continues until the Decree 59/2011/ND-CP dated July 18, 2011. In the mid-1980s, because of the poor performance of state-owned enterprises, the government decided to restructure the public sector and selected privatization process as an important strategy. Privatization through equitization in Vietnam is the process of the changing corporate ownership of former SOEs with the purpose for mobilizing capital from private investors to increase financial resources, to invest in new technology, and to allow the employees to be shareholders. It was expected that equitization would change the ownership of the Stated-owned enterprises (SOEs), attract investment from the private sector, enhance worker participation by turning them into company shareholders and improve SOEs performance. The Vietnamese Government has favored firm-by-firm privatization and privatization IPOs have been the dominant privatization method in the process from 2005. By November 20, 2011 there were 3,951 SOEs privatized. Among them, six SOEs were privatized in 2011 because of the unstable macro-economic factors, and the slowdown of securities market, according to the report of the Ministry of Planning and Investment. Until recently only small and medium SOEs in less important economic sectors such as light industries, trading and hotel services were privatized. The government still dominates in the industries of telecommunication, airlines, natural gas, and railroads, and is the dominant player in large firms which are natural monopolies such as utilities, security and national defense. Therefore, privatization in Vietnam is still in its infancy and its validity as part of a long-term SOE reform strategy is still being actively debated.

According to Stiglitz (1999), the expectation that improved performance would come automatically from privatization is wrong. Most of the theoretical arguments for privatization predict that privatization is supposed to bring about positive organizational changes if it is in a competitive market environment. The change should lead to the improvement of privatized firm performance.

Although the research on the effectiveness of privatization on performance and efficiency of privatized firms in the world is extensive, there are few such studies focused on the Vietnamese experience. The primary objective of this study is thus to assess the corporate performance of privatized firms and to determine the factors improving performance. We specifically assess the impact of state ownership level on corporate performance of privatized firms and attempt to determine the impact of corporate culture and employee commitment on corporate 
performance in privatized firms. Using data collected from a survey questionnaire, we find that only organizational integration significantly affects the performance of privatized firms and that employee and customer satisfactions are among the most important drivers of corporate performance. There is also evidence to suggest that privatized firms with less state ownership perform better than those with more state ownership.

The remainder of the article is organized as follows. Section 2 reviews both the theoretical and empirical literature on the effects of privatization on firm performance as well as on organizational culture and commitment of privatized firms. Section 3 represents conceptual model and outlines the major research hypotheses. Section 4 discusses measurement, reliability, and presents the profile of respondents. Section 5 describes the data collection. Section 6 reports and discusses the empirical results. Section 7 concludes the paper.

\section{LITERATURE REVIEW}

Privatization includes a very broad range, from very little government involvement to the establishment of partnerships between government and private service providers where the government is still the dominant player. According to Cunha \& Cooper (1998) privatization is a commitment to start a large-scale change process, which takes place both in terms of the external and internal environments. While changes in external environment derive mainly from the introduction of competition and from deregulation, changes in the internal environment of privatized companies are expected to complement the ownership status change, particularly in organizational goals. Zahra and Hansen (2000) describe privatization as a strategy promoting the forces of a free market system by transforming state-owned enterprises into private companies and changing their ownership and management systems. We adopt these considerations in this article.

\subsection{Outcomes of Privatization}

Many governments privatized their state-owned enterprises with the hope that their performance would be improved through the effects of private ownership. Privatization reduces the public sector deficit and constraints on corporate financing. It improves former SOEs' efficiency and productivity deriving from the giving market incentives to managers and workers (Parker and Hartley, 1991; Parker, 1992). By transferring management control to private sector, privatization develops coherent corporate strategies and focuses enterprises on value maximization (Megginson, 1992), especially in transitional economies.

Frydman et al. (1999) examine the influence of ownership structure on performance by using a sample of 90 state-owned and 128 privatized companies in Czech Republic, Hungary, and Poland. They find that privatization to an outside owner also added to productivity growth. Insider-controlled firms were less likely to restructure, but outsider-controlled firms grew faster.

Wei et al. (2003) examine the pre- and post- privatization financial and operating performance of 208 Chinese companies privatized in 1990-1997. They find that sales and sales efficiency are improved while leverage declines significantly following privatization.

Mathur and Banchuenvijit (2007) examine changes in the financial and operating performance of 103 firms worldwide that were privatized during 1993-2003 in both emerging markets and developed countries. The empirical results show increases in profitability, operating efficiency, capital spending, output, and dividend payments, but decreases in leverage and total employment. Kofi and Henk (2007) analyze the effect of privatization in Ghana by surveying 300 workers in privatized and state-owned enterprises. Their findings indicate a significant positive relationship between privatization and job satisfaction.

Boubakri et al. (2009) investigate the effects of privatization for a panel of 189 firms from strategic industries headquartered in 39 countries, and privatized between 1984 and 2002. They look at the change in ownership and post privatization control by the government and assess the changes in firm performance. Their results reveal negative effects of state ownership on profitability and operating efficiency. Bai et al. (2009) use a comprehensive panel data set of China's state-owned enterprises to investigate the impacts of privatization on firm performance indicators. They document that the privatization of China's state-owned enterprises led to increase sales and labor productivity. 
Huang and Wang (2010) explore the effect of full privatization on the performance of Chinese listed companies. Full privatization in China is defined transferring the ultimate control of a state-owned company from the government to private owners. They use a sample of 127 Chinese listed companies that have had controlling blocks transferred from the government to private owners. They show that firm performance has improved significantly following this transfer. Efa (2010) examine the relationship between privatization of state-owned enterprises (SOEs) and performance by using a survey questionnaire. Responses were obtained from 86 managers in 86 organizations, comprised of SOEs, privatized firms and private enterprises in Indonesia. The author explores the mechanisms by which privatization affects corporate performance through corporate culture, employee commitment, and employee and customer satisfaction. It is found that only privatization policies that bring positive organizational changes fundamentally different from SOEs and suitable to a competitive market environment lead to improved firm performance.

\subsection{Organizational Culture and Corporate Performance}

Privatization has been used as a strategy of basic change for SOEs. Political and business leaders assume that privatization would create a context developing a supportive culture for corporate performance (Cunha and Cooper, 2002). The role of corporate culture and its impact on performance has been documented in the academic literature. "Corporate culture" and "organizational culture" dominated management theory in the late 1970s and 1980s (Schein 1984 and references therein). Organizational culture was used to explain the economic successes of Japanese over American firms, through the development of a highly motivated workforce, committed to common set of core values, beliefs and assumptions (Furnham and Gunter, 1993). The link between corporate culture and increased productivity was demonstrated by Ouchi (1981). Deal and Kennedy (1982) consider the importance of a "strong" culture in achieving successful organizational performance. However, the literature is limited on how corporate culture and individual employees in the privatized firms are affected by privatization (Cunha and Cooper, 2002).

In a pioneer work, Scholz (1987) considers organizational culture as the implicit, invisible, intrinsic, and informal consciousness of the organization, which guides the behavior of the individuals. Schein (1990) defines organizational culture as a pattern of basic assumptions that a group has invented, discovered or developed in learning to cope with its problems of external adaptation and internal integration, and that have worked well enough to be considered valid, and therefore, should be taught to new members as the correct way to perceive, think, and feel in relation to those problems. Schein (1999) extends this concept to include also the structure and control system generating behavioral standards within organizations.

The identification of different types of culture is crucial for studies on ownership structure, organizational culture, and firm performance. Harrison (1972) classifies organizational cultures using the degree of formalization and centralization as criteria. Deal and Kennedy (1982) differentiate cultures in terms of the speed of feedback and the amount of risk taken. Quinn and Rohrbaugh (1983) develop the competing values model which incorporates two sets of competing values along two axes: (1) the control/flexibility dilemma which refers to preferences about structure, stability, and change, and (2) the people/organization dilemma which refers to differences in organizational focus. From these two axes emerge four quadrants which reflect four types of culture, namely rational, hierarchical, developmental, and group. Even though these cultural approaches can be used to identify the organizational culture of business organizations, the cultural approach suggested by Cunha and Cooper (2002) is more relevant to examine corporate culture of SOEs and privatized firms because it is the process-oriented approach which reflects the change of organization to cope with its problem of external adaptation and internal integration. Organizational integration reflects openness of internal communication and co-operation between individuals and units. Performance orientation concerns responsibility of meeting objectives and results, and merits and rewards. People orientation reflects the extent of concern the organization showing for its members and their development, as well as the individual feeling of belonging to a team. Market orientation deals with company responsiveness to market opportunities and benchmarking. In this article, we also adopt this concept of corporate culture.

Deshpande et al. (1993) investigate the relationship between culture and business performance in Japanese companies. They find that companies with cultures that stress competitiveness (market culture) and entrepreneurship (adhocracy cultures) outperform those with cultures focusing on internal cohesiveness (clan cultures) or rules (hierarchy cultures). 
Van der Post et al. (1998) examine the relationship between organizational culture and the financial performance of organizations in South Africa. They find that organizational culture has a positive relationship with the financial performance of the firms. Firms with more effective financial performance differ from those firms that are not financially effective because of the difference of organizational culture dimensions.

Deshpande and Farley (1999) study the relationship between corporate culture and performance in Indian and Japanese firms. Their results show that the most successful Indian firms had an entrepreneurial culture, while the Japanese firms had an entrepreneurial and competitive culture. Moreover, entrepreneurial and competitive cultures perform better than consensual and bureaucratic cultures because they are more innovative and risk taking.

While organizational culture is considered as an important predictor of firm's performance in a number of recent studies, the results of previous studies suggest that the impact of different types of organizational culture on firm's performance will differ substantially (see George and Irma, 2011 for a literature review).

\subsection{Employee Commitment and Corporate Performance}

Commitment is defined by Porter (1974) in terms of a belief in, and acceptance of, the goals and values of organization and/or profession; a willingness to exert considerable effort on behalf of the organization; and desire to attain membership in the organization. Allen and Meyer (1990) suggest that there are three types of employee commitment. Affective commitment refers to the employee emotional attachment to, identification with, and involvement in the organization. Continuance commitment indicates commitment based on the costs of employees associate with leaving the organization. Normative commitment relates to the employee feelings of obligation to remain with the organization.

Employee commitment has been one of the most popular organizational research subjects because employee commitment has an impact on performance and is significantly related to the financial success of bank branches (Benkhoff, 1997). Kontoghiorghes and Bryant (2004) find that employee commitment exhibits a significant and positive correlation with the productivity indicators and cost effectiveness.

The relationship between privatization, the firm's work environment and employee attributes has received less attention (Megginson and Netter, 2001). Factors such as trust and reciprocity can play a significant role in the principal-agent relationships that exist within the firm. As agents, employees enter a firm with certain needs, and the ability of the firm and its management (the principal) to provide an environment in which they can satisfy these needs determines employee commitment and subsequent behavior (Mowday et al., 1982).

Share ownership of employees has become a key feature of privatization. A committed employee stays with the organization long term, attends work regularly, protects organization's assets, and accepts organization goals (Meyer and Allen, 1997). Turning SOE employees into their shareholders through privatization increases their commitment to the privatized firms guaranteeing higher performance. Warren (2003) assumes that SOEs are officially owned by "the whole people", with the state being the de facto representative of the people. Workers' compensation is consistent with the principle of "distribution to labor". In privatized firms, the work behaviors of workers are monitored and their incomes are now tied to their job performance. Their labor is sold to investors as commodities. The dividends they earn are higher than the saving rate and the amount they get is somewhat significant as an absolute amount. Employee stock ownership plans in privatized firms creates ownership satisfaction which will generate more favorable attitudes towards the company. This in turn will lead to changes in behaviors, such as greater personal effort, and a reduced propensity to quit. These changes in individual behaviors will be reflected in improvements in performance.

\section{RESEARCH MODEL AND HYPOTHESES}

The Figure 1 shows our model with expected relationships between ownership structure, corporate culture, employee commitment and firm performance variables. The equitization policy has divided Vietnamese SOEs into two groups: state owned enterprises with $100 \%$ state capital and privatized firms with a mixed ownership structure. Typically these firms are a combination of state, employee and other private ownership including foreign ownership. 


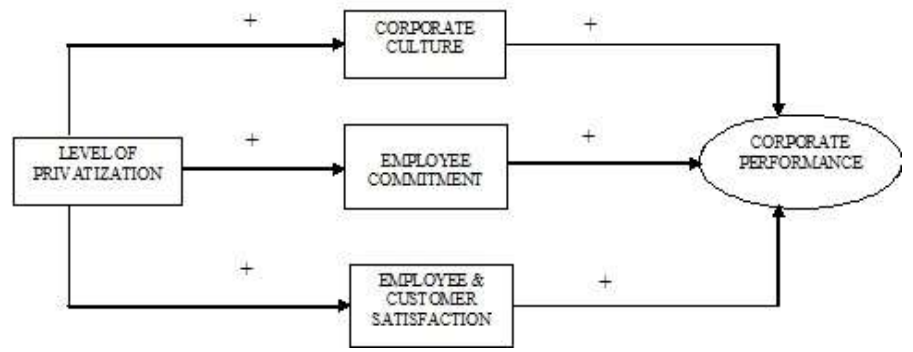

Figure 1: Expected Relationships between Ownership Structure, Corporate Culture, Employee Commitment and Firm Performance

In our model, corporate performance is the dependent variable. The independent variables include organizational culture, employee commitment, employee satisfaction, and customer satisfaction. The set of control variables is comprised of state shareholding, industry, year equitized, gender, position, age, and experience.

Equitization in Vietnam changes ownership, which gives employees the right to participate in sharing ownership and the financial results of their enterprises. This combination is expected to lead increased employee commitment in privatized firms. The new ownership structure is expected to relate to new organizational cultural values. Employee commitment is likely to positively impact corporate performance. The equitization of SOEs in Vietnam would be expected to increase employee and customer satisfaction leading to increase corporate performance. The significant differences between privatized firms and SOEs are likely to be observed. Based on the above research model, we are able to test the following eleven detailed hypotheses.

H1: Privatized firms perform significantly better than SOEs.

H2: For privatized firms, the higher the percentage of state shareholding, the lower the performance.

H3: For privatized firms, the higher organization integrated the corporate culture, the better the performance.

H4: For privatized firms, the higher the people oriented the corporate culture, the better the performance.

H5: For privatized firms, the higher the performance oriented the corporate culture, the better the performance.

H6: For privatized firms, the more market oriented the corporate culture, the better performance.

H7: For privatized firms, the higher affective commitment of employees, the better the performance.

H8: For privatized firms, the higher normative commitment of employees, the better the performance.

H9: For privatized firms, the higher the continuance commitment of employees, the better the performance.

H10: For privatized firms, the higher the satisfaction of employees, the better the performance.

H11: For privatized firms, the higher the satisfaction of customer, the better the performance.

\section{DATA COLLECTION}

The sample includes two kinds of firms, state of enterprises with state ownership of 100 percent and privatized firms which were privatized from 1998 to 2005. Respondents are those who have been working for these surveyed firms as managers, staffs or workers. The purposive sampling technique was used. Firstly, the part-time MBA students of University of Economics of Hochiminh City working at state owned enterprises and privatized firms were identified. Next, the purpose of the survey and the meaning of each question in the questionnaire were explained. Finally, the questionnaire were delivered to respondents through MBA students and collected after one week. 
Table 1: Respondent Profiles

\begin{tabular}{|c|c|c|c|}
\hline \multicolumn{2}{|l|}{ Sex } & \multicolumn{2}{|c|}{ Age } \\
\hline Male & 61.9 & From 18 to less than 30 years old & 32.8 \\
\hline Female & 38.1 & From 30 to 45 years old & 48.1 \\
\hline Total & 100.0 & More than 45 years old & 19.1 \\
\hline Positi & & Total & 100.0 \\
\hline Manager & 33.2 & Experi & \\
\hline Staff & 57.2 & Less than 5 years & 33.3 \\
\hline Employee & 9.6 & From 5 to less than 10 years & 28.7 \\
\hline Total & 100.0 & From 10 to less than 15 years & 15.4 \\
\hline Title & & From 15 to less than 20 years & 12.4 \\
\hline Top manager & 30.2 & More than 20 years & 10.1 \\
\hline Middle manager & 23.3 & Total & 100 \\
\hline First line-manager & 46.6 & & \\
\hline Total & 100.0 & & \\
\hline
\end{tabular}

A total of 3,000 questionnaires were sent to SOEs and privatized firms located in HCM City through MBA students. Around 1000 questionnaires were collected back, but the number of valid responses received only is 790, representing a response rate of 26\%. Among these 790 valid questionnaires, 438 are collected from SOEs and 352 from privatized firms. Regarding industry there are 59\% are manufacturers, $34.6 \%$ are service companies and the rest are trade companies. Regarding shareholding in privatized firms, $32.7 \%$ are privatized firms with a state shareholding lower than $30 \%$; $43.2 \%$ with a state shareholding from $30 \%$ to $50 \%$, and $24.1 \%$ with a state share holding more than 50\%. The sample is appropriate for studying the change of ownership structure and organizational culture as it is composed of more than $75 \%$ privatized firms with the state shareholding less than $50 \%$.

Table 1 reports the profile of surveyed employees. They represent a broad range of title, gender, age, and experience. It is important to note that almost all respondents are over 30 years old and have more than 5 years working experience in their current company. The sample is appropriate to study organizational culture and employee commitment to organization as the respondents know much about the insightful changes of cultural issues in their respective companies.

\section{MEASUREMENT AND RELIABILITY}

\subsection{Measurement}

Ownership is used to measure the level of the privatization of state owned companies. The research sample is divided into two groups: the group of state owned enterprises with $100 \%$ state owned equity and the group of privatized firms. The second group of privatized firms is divided into three subgroups based on the proportion of state shareholding. The State holds less than $30 \%$ of the issued shares for the subgroup 1, from $30 \%$ to $50 \%$ for the subgroup 2, and more than $50 \%$ for the subgroup 3.

Corporate performance is measured by 5 items: productivity, sales, profits, return on assets, and return on equity. Respondents were asked to rank their company performance compared with other companies in the same industry. We use a five-point scale ranging from 1 to 5 , with one meaning very low, and five meaning very high.

Organizational culture consists of four constructs suggested by Cunha and Cooper (2002). The culture dimension scales are measured by a five-point Likert scale ranging from totally disagree to totally agree or not important at all to very important. Performance orientation is measured by 5 items. People orientation, which reflects the extent of concern the organization shows for its members and their development, as well as the individual feeling of belonging to a team is measured by 6 items. Organization integration, which reflects openness of internal communication and cooperation between individuals and units, is measured by 6 items. Market orientation, which deals with company responsiveness to market opportunities and benchmarking, is measured by 4 items. These items are presented in Table 2. 
Table 2: Corporate Culture Scales

\begin{tabular}{|c|c|}
\hline Cultural Constructs & 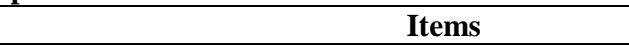 \\
\hline Performance orientation & $\begin{array}{l}\text { 1. Common goals } \\
\text { 2. Measuring performance } \\
\text { 3. Accountability for the end results } \\
\text { 4. Rewarded fairly } \\
\text { 5. Customers' benefits }\end{array}$ \\
\hline People orientation & $\begin{array}{l}\text { 1. } \text { Promotion based on individual competence } \\
\text { 2. Support for employees' learning } \\
\text { 3. Opportunities to do the best } \\
\text { 4. Rewarded based on task } \\
\text { 5. Promotion based on individual performance } \\
\text { 6. }\end{array}$ \\
\hline Organization integration & $\begin{array}{ll}\text { 1. } & \text { Responsibilities clearly defined } \\
\text { 2. } & \text { Job rules and regulation } \\
\text { 3. } & \text { Cooperation } \\
\text { 4. } & \text { Fully informed } \\
\text { 5. } & \text { Concern for employees } \\
\text { 6. } & \text { Strong sense of team } \\
\end{array}$ \\
\hline Market orientation & $\begin{array}{ll}\text { 1. } & \text { New products developed } \\
\text { 2. } & \text { Finding new markets } \\
\text { 3. } & \text { Concern for competitors' actions } \\
\text { 4. } & \text { Competitiveness }\end{array}$ \\
\hline
\end{tabular}

Employee commitment has three constructs: affective, continuance and normative commitment. Their scales are adapted from the scale framework of Allen and Meryer (1992) and measured by a five-point Likert scale ranging from "totally disagree" to "totally agree". Affective commitment, which refers to employees' emotional attachment to, identification with, and involvement in the organization, is measured by 4 items. Continuance commitment, which refers to commitment based on the costs of employee associate with leaving the organization, is measured by 4 items. Normative commitment referring to employees' feelings of obligation to remain with the organization is measured by 3 items. Employee satisfaction is measured by 5 items, salary, bonus, satisfaction with job and with income, and promotional opportunities. Customer satisfaction is measured by 2 items, satisfaction with product/service quality and delivery.

\subsection{Reliability}

Table 3 reports the results of the reliability test for all constructs' scales. The data are reliable if the Cronbach's alpha is equal to or above 0.7. The Cronbach's alpha of corporate performance, employee satisfaction, and customer satisfaction factors is higher than 0.7. This confirms that the scale is reliable. Similar results are obtained for organizational culture constructs (performance orientation, people orientation, organization integration, and market orientation) and employee commitment constructs (affective, normative, and continuance commitment), except for the continuance commitment where the reliability is not confirmed. However, it is acceptable for exploratory purposes.

Table 3: The Reliability of Measurement Scales

\begin{tabular}{|l|c|c|}
\hline \multicolumn{1}{|c|}{ Factors } & Number of Items & Cronbach Alpha \\
\hline Financial performance & 5 & .88 \\
Employee satisfaction & 5 & .87 \\
Customer satisfaction & 2 & .82 \\
\hline Performance orientation & 5 & .78 \\
People orientation & 5 & .83 \\
Organization integration & 6 & .84 \\
Market orientation & 4 & .75 \\
\hline Affective commitment & 4 & .72 \\
Normative commitment & 3 & .73 \\
Continuance commitment & 4 & .62 \\
\hline
\end{tabular}

Notes: this table presents the results of reliability test of measurement scales 


\section{HYPOTHESIS TESTING}

Table 4 reports Independent T- test results between privatized firms and SOEs in terms of corporate performance. The statistical analysis in Table 3 shows that both privatized firms and SOEs have a moderate performance with all mean values of corporate items lower than 4 . However privatized firms perform significantly better than SOEs in terms of profit and return on equity (mean difference $=0.156, p<0.05$; and $0.162, p<0.05$, respectively). There is no statistically significant difference between them in terms of productivity, and return on assets. SOEs have sales higher than privatized firms significantly. Thus, H1 which predicts that privatized firms perform better than SOEs is not fully accepted.

Table 4: Comparing Privatized Firms with SOEs for Corporate Performance Items

\begin{tabular}{|l|c|c|c|c|}
\hline \multirow{2}{*}{ Variables } & \multicolumn{2}{|c|}{ Mean } & Mean difference & $\begin{array}{c}\text { Significant } \\
(\boldsymbol{\alpha})\end{array}$ \\
\cline { 2 - 5 } & SOEs (N =438) & Privatized Enterprise (N = 352) & -0.085 & 0.104 \\
Productivity & 3.47 & 3.56 & 0.030 & 0.000 \\
Sales & 3.56 & 3.53 & -0.156 & 0.040 \\
Profit & 3.37 & 3.53 & -0.104 & 0.053 \\
Return on Assets & 3.26 & 3.37 & -0.162 & 0.023 \\
Return on Equity & 3.27 & 3.43 & \\
\hline
\end{tabular}

Table 5: Results of the ANOVA and Post Hoc Tests

\begin{tabular}{|l|c|c|}
\hline \multicolumn{1}{|c|}{ Variables } & ANOVA (F) & Bonferroni comparisons \\
\hline Productivity & 3.729 & $\mathrm{G} 1-\mathrm{G} 2^{*}, \mathrm{G} 1-\mathrm{G} 3, \mathrm{G} 2-\mathrm{G} 3$ \\
Sales & 12.389 & $\mathrm{G} 1-\mathrm{G} 2^{*}, \mathrm{G} 1-\mathrm{G} 3, \mathrm{G} 2-\mathrm{G}{ }^{*}$ \\
Profit & 19.374 & $\mathrm{G} 1-\mathrm{G} 2^{*}, \mathrm{G} 1-\mathrm{G} 3, \mathrm{G} 2-\mathrm{G} 3^{*}$ \\
Return on Assets & 16.774 & $\mathrm{G} 1-\mathrm{G} 2^{*}, \mathrm{G} 1-\mathrm{G} 3, \mathrm{G} 2-\mathrm{G} 3^{*}$ \\
Return on Equity & 16.833 & $\mathrm{G} 1-\mathrm{G} 2^{*}, \mathrm{G} 1-\mathrm{G} 3, \mathrm{G} 2-\mathrm{G} 3^{*}$ \\
\hline
\end{tabular}

Notes: ANOVA, analysis of variance; G1, privatized firms with state ownership less than 30\%; G2, privatized firms with state ownership from $30 \%$ to $50 \%$; G3, privatized firms with state ownership more than $50 \%$. * Significant at the 0.05 level.

To test the significance difference of corporate performance items with difference of state ownership in the three privatized firm groups, an ANOVA test and a post hoc test of Bonferroni have been performed. The results are summarized in Table 5. The values of 5 variables were found to be significantly high compared with the critical value for F-distribution at the 0.05 level. These findings imply that there is a significant relationship between the state ownership percentages in privatized firms with all corporate performance variables. However, the post hoc comparisons result in mixed results, which imply that there are remarkable differences in corporate performance under different state ownership status. There are significant differences between privatized firms with state ownership less than $30 \%$ and from $30 \%$ to $50 \%$ for all corporate performance variables. However, there is no significant difference between privatized firms with state ownership less than $30 \%$ and more than $50 \%$ with respect to all corporate performance items. Thus $\mathrm{H} 2$ cannot be concluded.

To test the relationship between organizational culture dimensions, employee commitment constructs and corporate performance, the linear regression test for five competitive models was used. Model 1 consists of predictors using only culture variables. Model 2 includes both culture and commitment variables. Model 3 includes the variables of model 2 and two other variables, employee satisfaction and customer satisfaction. Model 4 consists of variables of Model 3, and state shareholding, year equitized and industry dummy variables. The last three variables are converted into dummy variables, in which the state shareholding percentage more than $50 \%$ is equal to 1 , year equitized from 2002 and before is equal to 1 , and manufacturing firms is equal to 1 . Model 5 involves variables of Model 4, and experience, position, age and gender dummy variables. The last four variables are converted into dummy variables, in which the experience less than 15 years is equal to 1 , manager is equal to 1 , age less than 30 years old is equal to 1 , and male is equal to 1 .

Model 1 in Table 6 tests the relationship between corporate culture dimensions and performance of privatized firms. The results showed that corporate culture explains $27.5 \%$ of variance in corporate performance. There is a significantly positive impact of integration orientation, people orientation, and market orientation on 
corporate performance with $\beta=.271(\mathrm{p}<0.01), 0.250(\mathrm{p}<0.01)$, and $.114(\mathrm{p}<0.05)$, respectively. However, performance orientation does not significantly influence to corporate performance.

Table 6: Drivers Of Corporate Performance

\begin{tabular}{|c|c|c|c|c|c|c|c|c|c|c|}
\hline \multirow{2}{*}{ Variables } & \multicolumn{2}{|c|}{ Model 1} & \multicolumn{2}{|c|}{ Model 2} & \multicolumn{2}{|c|}{ Model 3} & \multicolumn{2}{|c|}{ Model 4} & \multicolumn{2}{|c|}{ Model 5} \\
\hline & Beta & Sig. & Beta & Sig. & Beta & Sig. & Beta & Sig. & Beta & Sig. \\
\hline $\mathrm{OI}$ & .271 & .000 & .249 & .000 & .139 & .019 & .136 & .022 & .151 & .011 \\
\hline $\mathrm{PeO}$ & .250 & .000 & .195 & .002 & -.037 & .532 & -.028 & .649 & -.014 & .825 \\
\hline PerfO & .006 & .905 & .011 & .833 & .062 & .189 & .069 & .145 & .073 & .127 \\
\hline MO & .114 & .038 & 137 & .015 & .062 & .221 & .055 & .283 & .055 & .280 \\
\hline $\mathrm{AC}$ & - & - & .109 & .095 & -.006 & .922 & .028 & .652 & .015 & .816 \\
\hline $\mathrm{NC}$ & - & - & -.020 & .705 & .004 & .929 & .002 & .968 & -.001 & .979 \\
\hline $\mathrm{CC}$ & - & - & .015 & .808 & .014 & .556 & -.029 & .589 & -.037 & .499 \\
\hline ES & - & - & - & - & .473 & .000 & .450 & .000 & .437 & .000 \\
\hline $\mathrm{CS}$ & - & - & - & - & .163 & .001 & .167 & .001 & .156 & .003 \\
\hline StateD & - & - & - & - & -.007 & .892 & 年- 024 & .630 & -.020 & .681 \\
\hline YearD & & & & & & & .059 & .239 & .076 & .141 \\
\hline IndD & & & & & & & .033 & .492 & .017 & .720 \\
\hline GenD & & & & & & & & & .016 & .714 \\
\hline AgeD & & & & & & & & & -.069 & .147 \\
\hline PosD & & & & & & & & & .059 & .193 \\
\hline ExpD & & & & & & & & & .009 & .843 \\
\hline $\mathrm{R}^{2}$ & \multicolumn{2}{|c|}{$27.5 \%$} & \multicolumn{2}{|c|}{$28.4 \%$} & \multicolumn{2}{|c|}{$43.9 \%$} & \multicolumn{2}{|c|}{$44.5 \%$} & \multicolumn{2}{|c|}{$45.6 \%$} \\
\hline
\end{tabular}

Notes: this table reports the regression results for corporate performance as dependent variable. OI: Organization integration; PeO: People orientation; PerfO: Performance orientation; MO: Market orientation; AC: Affective commitment; CC: Continuance commitment; NC: Normative commitment; ES: Employee Satisfaction; CS: Customer Satisfaction; StateD: State shareholding Dummy; YearD: Year equitized Dummy; AgeD: Age Dummy; GenD: Gender Dummy; PosD: Position Dummy; ExpD: Experience Dummy.

Model 2 including corporate culture and employee commitment variables explains $28.4 \%$ of corporate performance. The corporate culture factors are significant but all three employee commitment factors do not influence on corporate performance significantly. Thus, organization integration, people orientation, and market orientation are the most important factors in explaining the performance of privatized firms.

Model 3 with the participation of employee satisfaction and customer satisfaction variables explains $43.9 \%$ of the variance in corporate performance. This is an increase of $15.5 \%$ over model 2. In this Model, three factors including organization integration, employee and customer satisfaction influence significantly on corporate performance of privatized firms. Employee and customer satisfaction are the most important factors over all.

Model 4 adds privatization variables. $\mathrm{R}^{2}$ increases slightly $(0.6 \%$ over model 3$)$. These results are significant. Model 5 adds demographic variables. This improves $\mathrm{R}^{2}$ to $45.6 \%$ an increase of $1.1 \%$ over model 4 . Overall employee and customer satisfaction with organization integration are the key factors in increasing the performance of privatized firms. accepted.

Thus, there are three hypotheses (H3, H10, and H11) accepted, while H4, H5, H6, H7, H8, and H 9 are not

\section{DISCUSSIONS AND CONCLUSION}

\subsection{Corporate Performance of Privatized Firms and SOEs}

This study found that privatized firms perform better than SOEs in terms of employee satisfaction and customer focus. There is no significant difference in financial performance between the two groups. The employee satisfaction and customer focus levels of privatized firms are higher than those of SOEs. Privatized firms perform better than SOEs only in terms of profit and return on equity. Productivity, and return on assets have no significant difference between privatized firms and SOEs, while sales of SOEs is higher than that of privatized firms 
significantly. This finding is consistent with the results of Perevalov et al. (2000) and Omran (2004). Perevalov et al. (2000) study the performance of 189 privatized industrial enterprises in 1992-1996 and showed that privatization improved little performance of Russia enterprises. Omran (2004) examines the performance of 54 newly privatized Egyptian firms against a matching number of SOEs. Their analyses showed that privatized firms do not exhibit significant improvement in their performance changes relative to SOEs.

Since the opening of the Vietnamese market, the competitive pressure in the domestic market has increased significantly. In this situation all firms, privatized firms and SOEs, have to find an effective way to survive and develop. According to Fare et al. (1985), when both private and public firms are exposed to the same competitive pressures and market signals, they are expected to perform efficiently, regardless of ownership structure.

Having an excess of unskilled labor but lacking qualified employees is a major handicap for former SOEs, however after privatized they do not lay their employees off. They retain qualified employees, recruit new qualified labor and retrain current unskilled employees. Privatized firms can pay their employees higher and reward them based on company performance without government restrictions on employee payroll. This leads to an increase in employee satisfaction. Asiedu and Folmer (2007) find a significant positive relationship between privatization and job satisfaction. Education and the availability of training opportunities were strong determinants of job satisfaction, a component of employee satisfaction in privatized enterprises.

\subsection{Corporate Performance of Privatized Firms with Different State Ownership Proportions}

The results also show that the state ownership proportion has a negatively effect on privatized firm performance. Privatized firms with a state ownership proportion less than $30 \%$ perform better than privatized firms with the proportion ranging from 30 to $50 \%$. This is consistent with the finding of Boubakri et al. (2009), stateownership impacted negatively on profitability and operating efficiency. While government brings about advantages to SOEs, market discipline and competitive pressure bring about positive outcomes for privatized firms.

The results of this study also show that privatized firms with less state ownership have significantly higher financial performance than other firms. This finding is consistent with the finding of Truong et al. (2006) who measure the impact of privatization on firm performance in Vietnam and found significant increases in profitability, sales revenues, efficiency, and employee income. This result is also supported by Bai et al. (2009) who found that the privatization of China's state-owned enterprises increased sales and productivity, but only when state ownership was reduced to a minority position.

In this study more privatized firms have significantly higher employee satisfaction and customer focus. The finding is consistent with the findings of Kofi and Henk (2007), Yonnedi (2010), and Mowday et al (1982). Mowday et al. (1982) indicated there is a significant relationship between privatization and positive employee attitudes and behaviors. In privatized firms, worker behavior is monitored and their incomes are tied to job performance. The dividends they earn usually are higher and are a significant incentive (Warren, 2003). These incentives increase their satisfaction. Privatized firm have higher customer focus because they usually operate in a highly competitive environment.

\subsection{Corporate Culture and Employee Commitment of Privatized Firms}

We find that privatized firms have a higher market cultural orientation. This finding is consistent with the findings of Longencker and Popovski (1994), but inconsistent with the findings of Cunha and Cooper (2002). Longencker and Popovski (1994) found that privatization is essential to develop a more market or customer-oriented culture. However, Cunha and Cooper (2002) document no significant differences for market orientation between public firms and privatized firms. Most privatized firms in Vietnam are more focused on the market. They create customer service centers and do customer satisfaction surveys regularly. SOEs only do so rarely. These privatized firms have more market responsiveness.

Privatized firms also have a higher continuance commitment. The finding is consistent with the finding of Cunha and Cooper (2002), who find that the continuance commitment level of privatized firms is significantly 
higher than in SOEs. Smith (1986) explained that employee share ownership gives employee a chance to receive a share of the profit of the firm employing them. Profit sharing increases employee involvement and interest in their company. This increases their sense of commitment. Privatized firms usually pay their employees higher than SOEs and reward them based on company performance without government employee payroll restrictions. Employees in privatized firms also share their company's profit through the Employee Share Ownership Plan (ESOP) which is very popular in Vietnamese privatized firms. These benefits increase continuance commitment in privatized firms.

\subsection{The Predictors of the Corporate Performance of Privatized Firms}

The cultural orientations of organization integration, people and market significantly positively impact financial performance. This finding is consistent with the findings of Cunha and Cooper (2002). Privatization has brought about major organizational changes of privatized firms related to a more competitive market environment. These positive organizational changes led to significant performance improvements (Yonnedi, 2010).

For privatized firms, employee commitment does not significantly positively impact financial performance. The finding is opposite to the findings of Zabid et al. (2003).

Employee satisfaction and customer focus are important factors influencing financial performance. For privatized firms, employee shareholders see financial value. Privatized managers pay more attention to the market. Customer focus becomes a critical performance emphasis in many privatized firms. To respond rapidly to the changes in customer taste and competitor activities, internal communication and information sharing provide objectives to increase performance. Employee satisfaction and customer focus through organization integration are the key factors in increasing the financial performance of privatized firms.

These findings recommend that privatizing governments should lower state shareholding in privatized firms to improve their performance. The involvement of private ownership makes firms' management to respond appropriately and quickly to the change of economic trends and economic factors such as globalization and competition pressure.

There are many cultural dimensions existing together in an organization. Organization integration is the predictor of corporate performance of privatized firms. However no commitment construct has a positive impact on corporate performance. These findings imply that privatized firms should develop organization integration culture dimensions to support the improvement of corporate performance.

However, our research findings might not be generalizable to other countries since they are based on a study conducted in one country with small sample size. In addition, the surveyed firms were not randomly selected but based on personal connections. The qualitative information was gathered from the interviewing of few people based on personal relations. The selection criteria, all surveyed privatized firms' performance is not capable of representing the typical performance of privatized firms in Vietnam. The shortcomings in the qualitative study still constitute a potential selection bias threat and weaken the generalizability. Finally, the study uses the perceived value measurement instead of the actual performance. Future research may focus on the combination of accounting data and perceived measurement so that the findings are more precise and valuable.

\section{AUTHOR INFORMATION}

Dr. Thi Quy Vo is a senior lecturer at the University of Economics of Ho Chi Minh City and the Director of Academic Programs at Sales \& Marketing Executives International Vietnam. Vo's fields of teaching and research include Financial Management, Risk Management, Business Planning, Sales Management, Organizational Culture and Corporate Performance, and Privatization. Her research articles have appeared in International Journal of Economic and Finance, DEPOCEN, and Economic Development Review. E-mail: quy@ueh.edu.vn (Corresponding author)

Dr. Fredric William Swierczek is director of Master of Business Administration Program (International Program) (IMBA) and Doctoral Program in Business (DPB), Faculty of Commerce and Accountancy, Thammasat University. 
His fields of teaching and research include Cross-culture Management, Asian Business, Organizational Behavior and Change, and Policy Management. Since 1980, he has written many articles on Cross Culture Management, Asian Business, Strategic Management, Organizational Behavior and Change in Asia Pacific Business Review, Journal of Enterprising Culture, International Journal of Entrepreneurship and Innovation, Asian Academy of Management Journal, Journal of Organizational Change Management. E-mail: fredric@tu.ac.th

Dr. Duc Khuong Nguyen is a Professor of Finance and Deputy Director for Research at IPAG Business School (France). He holds a PhD in Finance from the University of Grenoble II (France) and a HDR (Habilitation for Supervising Scientific Research) degree from University of Cergy-Pontoise (France). His research articles are published in various refereed journals such as Journal of Banking and Finance, Journal of International Money and Finance, Journal of International Financial Markets, Institutions and Money, and Quarterly Review of Economics and Finance. Dr. Nguyen has also edited several books on corporate governance and CSR issues. E-mail: duc.nguyen@ipag.fr

\section{REFERENCES}

1. Allen, N.J., Meyer, J.P. (1990). The Measurement and Antecedents of Affective, Continuance and Normative Commitment to the Organization. Journal of Occupational Psychology, 63, 1-18.

2. Asiedu, K.F., Folmer, H. (2007). Does Privatization Improve Job Satisfaction? The Case of Ghana. World Development, 35(10), 1779-1795.

3. Bai, C. E., J. Lu, \& Z. Tao (2009). How Does Privatization Work in China? Journal of Comparative Economics, 37(3), 453-470.

4. Benkhoff, B. (1997). Ignoring Commitment is Costly: New Approaches Establish the Missing Link between Commitment and Performance. Human Relations, 50, 701-726.

5. Bishop, M., Thompson, D. (1994). Privatization in UK: internal organization and productive efficiency. Privatization and Economic Performance. Oxford University Press, Oxford.

6. $\quad$ Boubakri, N., Cosset, J.C., Omrane, G. (2009). From State to Private Ownership: Issues from Strategic Industries. Journal of Banking \& Finance, 33, 367-379.

7. Cunha, R.C., Cooper, C.L. (1998). Privatization and the Human Factor. Journal of Applied Management Studies, 7(2), 201-210.

8. Cunha, R.C., Cooper, C.L. (2002). Does Privatization Affect Corporate Culture and Employee Well-being? Journal of Management Psychology, 17(1), 21-49.

9. Deal, T.E., Kennedy, A.A. (1982). Corporate Culture. Addison-Wesley, Reading, MA.

10. Deshpande, R., Farley, J. (1999). Executive Insights: Corporate Culture and Market Orientation: Comparing Indian and Japanese Firms. Journal of International Marketing, 7(4), 111-127.

11. Desphande, R., Farley, J.U., Webster, F.E. (1993). Corporate Culture, Customer Orientation, and Innovativeness in Japanese Firms: A Quadred Analysis. Journal of Marketing, 57, 23-27.

12. Fare, R., Grosskopf, S., Logan, J. (1985). The Relative Performance of Publicly-owned and Privatelyowned Electric Utilities, Journal of Public Economics, 26, 89-106.

13. Farinós, J.F., García, C.J., Ibáñez, A.M. (2007). Operating and Stock Market Performance of State-owned Enterprise Privatizations: The Spanish Experience. International Review of Financial Analysis, 16, $367-$ 389.

14. Frydman, R., Gray, C.W., Hessel, M., Rapaczynski, A. (1999). When Does Privatization Work? The Impact of Private Ownership on Corporate Performance in Transition Economies. Quarterly Journal of Economics, 114(4), 1153-1191.

15. Harrison, R. (1972). Understanding Your Organization's Character. Harvard Business Review, May-June, 119-128.

16. Huang, Z., Wang, K. (2010). Ultimate Privatization and Change in Firm Performance: Evidence from China, China Economic Review, 22, 121-132.

17. Kofi, F.A., Henk, F. (2007). Does Privatization Improve Job Satisfaction? The Case of Ghana. World Development, 35(10), 1779-1795.

18. Kontoghiorghes C., Bryant, N. (2004). Exploring Employee Commitment in a Service Organization in the Health Care Insurance Industry. Organization Development Journal, 22(3), 59-73. 
19. Mathur, I., Banchuenvijit, W. (2007). Post-Privatization Organization Ownership Structure and Performance: The Effects of Privatization on the Performance of Newly Privatized Firms in Emerging Markets. Emerging Markets Review, 8, 134-146.

20. Megginson, W., Netter, J.N. (2001). From State to Market: A Survey of Empirical Studies on Privatization. Journal of Economic Literature, 39, 321-389.

21. Megginson, W., Nash, R., Randenborgh, M. (1992). Efficiency gains from Privatization: An International Empirical Analysis. Terry College of Business, University of Georgia, GA.

22. Meyer, J.P., Allen, N.J. (1997). Commitment in the Workplace, Theory, Research and Application. Thousand Oaks, London, New Delhi.

23. Omran, M. (2004). The Performance of State-Owned Enterprises and Newly Privatized Firms: Does Privatization Really Matter? World Development, 32(6), 1019 -10 41.

24. Parker, D., Hartley, K. (1991). Do Changes in Organizational Status Affect Financial Performance? Strategic Management Journal, 12, 631-641.

25. Parker, D. (1992). Agency Status, Privatization and Improved Performance: Some Evidence from the UK. International Journal of Public Sector Management, 5(1), 30-38.

26. Schein, E.H. (1984). Coming to a New Awareness of Organizational Culture. Sloan Management Review, 25, 3-16.

27. Schein, E.H. (1990). Organizational Culture. American Psychologist, 45, 109-119.

28. Schein, E.H. (1999). The Corporate Culture Survival Guide, Jossey-Bass, San Francisco, CA.

29. Scholz, C. (1987). Corporate Culture and Strategy: the problem of strategic fit. Long Range Planning, 20(4), 78-87.

30. Stiglitz, J. (1999). Whither Reform? Ten Years of the Transition. Paper presented at the Annual World Bank Conference on Development Economics, Washington, DC.

31. Truong, D.L., Lanjouw, G., Lensink, R. (2006). The Impact of Privatization on Firm Performance in a Transition Economy - The Case of Vietnam. Economics of Transition, 14(2), 349-389.

32. Yonnedi, E. (2010). Privatization, Organizational Change and Performance: Evidence from Indonesia. Journal of Organizational Change, 23, 537-563.

33. Van der Post, W.Z., Deconing, T.J., Smith, E.V. (1998). The Relationship between Organizational Culture and Financial Performance: Some South African Evidence. South African Journal of Business Management, 29(1), 30-41.

34. Wei, Z., Varela, O., D'Souza, J., Hassan, K. (2003). The Financial and Operating Performance of China's Newly Privatized Firms. Financial Management, 32, 107-126.

35. Zahra, S.A., Hanse, C.D. (2000). Privatization, Entrepreneurship, and Global Competitiveness in the 21st Century. Competitiveness Review, 10(1), 83-104. 


\section{NOTES}

